\title{
Association of Changes in Bombesin Immunoreactive Neuroendocrine Cells in Lungs of Newborn Infants with Persistent Fetal Circulation and Brainstem Damage Due to Birth Asphyxia
}

\author{
J. E. GILLAN, K. E. PAPE, AND E. CUTZ \\ Department of Pathology, Rotunda Hospital, Dublin, Ireland [J.E.G.] and Department of Pathology [E.C.] and \\ Department of Neonatology [K.E.P.], The Hospital for Sick Children, Toronto, Canada
}

\begin{abstract}
The pulmonary neuroendocrine (NE) cells, from 16 term infants dying at 1-4 days of age from birth asphyxia, were immuno stained for bombesin-like immunoreactivity by the immunoperoxidase method. The distribution and frequency of bombesin-immunoreactive NE cells were quantified morphometrically and correlated with the presence or absence of brainstem function and persistent fetal circulation (PFC). In infants with loss of brainstem function, the frequency of bombesin immunoreactive NE cells was significantly increased compared to infants with intact brainstem function, i.e. meconium aspiration with PFC. Infants with brainstem injury, with one exception, failed to develop PFC. Pathological changes in the tegmentum of the brainstem, i.e. containing the respiratory center, correlated in nine of 10 cases with loss of brainstem function. These data suggest an inverse relationship between brainstem function, release of bombesin-like peptide from the pulmonary NE cells and the functional state of the pulmonary vasculature. Intact brainstem function appears to be essential for both the release of bombesin-like peptide from the NE cells and for pulmonary vasoconstriction leading to PFC; absence of brainstem function is, on the other hand, associated with failure to release bombesinlike peptide and loss of PFC type reactivity in the pulmonary vasculature. However, it appears unlikely that bombesin itself is a direct mediator of pulmonary vasoconstriction. (Pediatr Res 20: 828-833, 1986)
\end{abstract}

\section{Abbreviations}

NE, neuroendocrine

NEB, neuroepithelial bodies

PFC, persistent fetal circulation

The pulmonary NE system consists of a population of specialized cells located in the epithelial lining of the conducting airways where they are thought to exert local paracrine influence. Pulmonary NE cells occur singly, in twos and threes, and in larger clusters referred to as NEB. While these cells were first described by Feyrter (1) in 1938 as clear cells with possible paracrine function, it was not until recently that their potential functional

Received August 25, 1985; accepted April 17, 1986.

Address correspondence and reprint requests to J. E. Gillan, Department of Pathology, Rotunda Hospital, Dublin 1. Ireland.

This work was supported by Grant MT-7641 to E.C. from the Medical Research Council of Canada. significance received attention. The first ultrastructural study of the NE cells was reported by Bensch et al. (2) in 1965 who described cells with neurosecretory granules in the bronchial mucosa of adult lung. Subsequent electron microscopic and histochemical studies (3-5), revealed that pulmonary NE cells exhibit many of the features of the APUD cells of Pearse (6), which prompted the suggestion that these cells might secrete vasoactive peptides (7). A tetradecapeptide bombesin was the first peptide reported in human neonatal lungs (8). This was subsequently followed by a report of two additional peptides namely calcitonin and leu-enkephalin in human neonatal and adult lungs (9). The term NE cells has gained general acceptance not only because of the presence of cytoplasmic neurosecretory granules, but also because these cells NEB appear to be innervated in both man, other mammals, and amphibians $(10,11)$. The strategic location of NEB at airway bifurcations $(5,12)$, their sensory innervation (10), and their degranulation with release of serotonin in response to hypoxia suggests a chemoreceptor function, sensing the composition of inhaled air. The purpose of the present study was to investigate the possible role of the brainstem in regulating the content of bombesin-like peptide in pulmonary NE cells of infants sustaining birth asphyxia with and without brainstem injury.

\section{CASE SELECTION}

Coded cases of neonatal deaths in term infants due to intrapartum asphyxia were obtained from the medical records at The Hospital for Sick Children, Toronto. The clinical and pathological data were reviewed with particular reference to pregnancy, delivery, the cause of asphyxia, postnatal neurological status, and respiratory function (See Tables 1-4). All infants required resuscitation following delivery. Those in whom breathing was established by 20 min and had an Apgar score greater than 6 at 10 min were considered to have intact brainstem function. Persistent ventilator dependence because of central apnea, absent brainstem reflexes, and a low Apgar score were accepted as brainstem damage. The presence of persistent fetal circulation was established indirectly from arterial blood gas levels while the infants were being ventilated on $60 \%$ or more oxygen. Cases with hyaline membrane disease, pulmonary hypoplasia, pulmonary embolism, primary persistent fetal circulation, or congenital malformation were excluded. Routine blocks of brain tissue taken at the time of autopsy and stained with hematoxylin and eosin were reviewed. Sections of the medulla, pons, hippocampus, thalamus, basal ganglia, and cerebral cortex from each case were examined. The gross description of the brain tissue in the autopsy report was reviewed to exclude malformations, inflammatory disease, 
Table 1. Clinical laboratory and morphometric data from cases with meconium aspiration alone

\begin{tabular}{|c|c|c|c|c|c|c|c|c|c|c|c|c|}
\hline Case & $\begin{array}{c}\text { Post- } \\
\text { mortem } \\
\text { interval }\end{array}$ & $\begin{array}{l}\text { Gestation } \\
\text { (wk) }\end{array}$ & Sex & Delivery & $\begin{array}{l}\text { Birth } \\
\text { wt }(g)\end{array}$ & $\begin{array}{l}\text { Age } \\
\text { (h) }\end{array}$ & $\mathrm{PFC}$ & $\mathrm{FIO}_{2}$ & $\begin{array}{c}\mathrm{PAO}_{2} \\
(\mathrm{~mm} \mathrm{Hg})\end{array}$ & $\begin{array}{l}\text { Cause of } \\
\text { death }\end{array}$ & $\begin{array}{c}\% \\
\text { Immuno- } \\
\text { positive } \\
\text { airways }\end{array}$ & $\begin{array}{c}\text { Immuno- } \\
\text { positive } \\
\text { ratio }\end{array}$ \\
\hline 1 & 4 & 40 & $\mathrm{~F}$ & CS* for fetal bradycardia & 4045 & 52 & + & 79 & 40 & Cardiac arrest & 83.0 & 0.52 \\
\hline 2 & 17 & 43 & $\mathrm{~F}$ & $\begin{array}{l}\text { CS for failed induction } \\
\text { of postmaturity }\end{array}$ & 2740 & 15 & + & 92 & 28 & $\begin{array}{l}\text { Bradycardia } \\
\text { Hypotension }\end{array}$ & 78.9 & 0.40 \\
\hline 3 & 24 & 38 & $\mathrm{~F}$ & $\begin{array}{l}\mathrm{VV} \dagger \text { meconium staining } \\
\text { of liquor }\end{array}$ & 2725 & 32 & + & 90 & 23 & Bradycardia & 78.0 & 0.54 \\
\hline 4 & 16 & 41 & $\mathrm{M}$ & $\begin{array}{l}\text { VV meconium staining } \\
\text { of liquor }\end{array}$ & 2690 & 78 & + & 81 & 40 & Cardiac arrest & 57.0 & 0.20 \\
\hline 5 & 18 & 40 & M & $\begin{array}{l}\text { VV meconium staining } \\
\text { of liquor }\end{array}$ & 3950 & 50 & + & 98 & 29 & Cardiac arrest & 81.0 & 0.55 \\
\hline 6 & 24 & 40 & M & $\begin{array}{l}\text { VV irregular fetal heart } \\
\text { rate }\end{array}$ & 3360 & 36 & + & 78 & 40 & Cardiac arrest & 85.0 & 0.42 \\
\hline Mean & $\begin{array}{r}17.2 \\
\pm 7.3\end{array}$ & $\begin{array}{r}40.4 \\
\pm 1.6\end{array}$ & & & $\begin{array}{r}3251.7 \\
\pm 629.8\end{array}$ & $\begin{array}{r}43.8 \\
\pm 21.5\end{array}$ & & $\begin{array}{r}86.3 \\
\pm 7.4\end{array}$ & $\begin{array}{r}33.3 \\
\pm 6.9\end{array}$ & & $\begin{array}{r}77.2 \\
\pm 9.3\end{array}$ & $\begin{array}{c}0.4 \\
\pm 0.12\end{array}$ \\
\hline
\end{tabular}

* Caesarian section.

$\dagger$ Vaginal vertex.

Table 2. Clinical laboratory and morphometric data from cases with meconium aspiration and brainstem damage

\begin{tabular}{|c|c|c|c|c|c|c|c|c|c|c|c|c|}
\hline Case & $\begin{array}{c}\text { Post- } \\
\text { mortem } \\
\text { interval }\end{array}$ & $\begin{array}{l}\text { Gestation } \\
\text { (wk) }\end{array}$ & Sex & Delivery & $\begin{array}{l}\text { Birth } \\
\text { wt (g) }\end{array}$ & $\begin{array}{l}\text { Age } \\
(\mathrm{h})\end{array}$ & $\mathrm{PFC}$ & $\mathrm{FIO}_{2}$ & $\begin{array}{c}\mathrm{PAO}_{2} \\
(\mathrm{~mm} \mathrm{Hg})\end{array}$ & Cause of death & $\begin{array}{c}\% \\
\text { Immuno- } \\
\text { positive } \\
\text { airways }\end{array}$ & $\begin{array}{l}\text { Immuno- } \\
\text { positive } \\
\text { ratio }\end{array}$ \\
\hline 7 & 56 & 39 & M & $\begin{array}{l}\mathrm{VV}^{*} \text { umbilical cord tight } \\
\text { around neck }\end{array}$ & 3420 & 5 & + & 94 & 25 & $\begin{array}{l}\text { Withdrawal of active life } \\
\text { support }\end{array}$ & 85 & 0.43 \\
\hline 8 & 18 & 39 & M & $\begin{array}{l}\text { VV fetal bradycardia } \\
\text { forceps delivery }\end{array}$ & 3200 & 144 & - & 30 & 81 & $\begin{array}{l}\text { Withdrawal of active life } \\
\text { support }\end{array}$ & 97 & 1.05 \\
\hline 9 & 18 & 38 & $\mathrm{~F}$ & $\mathrm{CS} \uparrow$ for failed forceps & 3500 & 120 & - & 36 & 113 & $\begin{array}{l}\text { Withdrawal of active life } \\
\text { support }\end{array}$ & 93 & 1.49 \\
\hline 10 & 12 & 40 & $\mathrm{~F}$ & CS for fetal distress & 3125 & 30 & - & 31 & 111 & Bradycardia & 98 & 0.76 \\
\hline 11 & 16 & 41 & M & VV; asphyxia at birth & 4500 & 25 & - & 72 & 77 & $\begin{array}{l}\text { Withdrawal of life sup- } \\
\text { port }\end{array}$ & 85.5 & 0.29 \\
\hline Mean & $\begin{array}{r}24.0 \\
\pm 18.1\end{array}$ & $\begin{array}{r}39.4 \\
\pm 1.1\end{array}$ & & & $\begin{array}{l}3549 \\
\pm 553.4\end{array}$ & $\begin{array}{r}64.8 \\
\pm 62.6\end{array}$ & & $\begin{array}{r}51.6 \\
\pm 0.1\end{array}$ & $\begin{array}{r}78.0 \\
\pm 32.8\end{array}$ & & $\begin{array}{r}91.7 \\
\pm 5.5\end{array}$ & $\begin{array}{r}0.80 \\
\pm 0.43\end{array}$ \\
\hline
\end{tabular}

* Vaginal vertex.

$\dagger$ Caesarian section.

Table 3. Clinical, laboratory, and morphometric data from cases with brainstem damage only

\begin{tabular}{|c|c|c|c|c|c|c|c|c|c|c|c|}
\hline Case & $\begin{array}{c}\text { Post- } \\
\text { mortem } \\
\text { interval }\end{array}$ & $\begin{array}{l}\text { Gestation } \\
\text { (wk) }\end{array}$ & Sex & Delivery & $\begin{array}{l}\text { Birth } \\
\text { wt }(g)\end{array}$ & $\begin{array}{l}\text { Age } \\
(\mathrm{h})\end{array}$ & $\mathrm{FIO}_{2}$ & $\begin{array}{c}\mathrm{PAO}_{2} \\
(\mathrm{~mm} \mathrm{Hg})\end{array}$ & Cause of death & $\begin{array}{c}\% \\
\text { Immuno- } \\
\text { positive } \\
\text { airways }\end{array}$ & $\begin{array}{c}\text { Immuno- } \\
\text { positive } \\
\text { ratio }\end{array}$ \\
\hline 12 & 10 & 42 & $\mathrm{~F}$ & VV* birth asphyxia & 3100 & 29 & 21 & 85 & Withdrawal of life support & 98 & 1.11 \\
\hline 13 & 12 & 40 & $\mathrm{~F}$ & $\mathrm{CS} \dagger$ for fetal bradycardia & 3175 & 3 & 42 & 140 & Withdrawal of life support & 96 & 0.83 \\
\hline 14 & 17 & 40 & M & $\begin{array}{l}\text { CS after fatal collapse of } \\
\text { mother }\end{array}$ & 2990 & 45 & 51 & 76 & Withdrawal of life support & 93 & 1.30 \\
\hline 15 & 22 & 40 & M & $\begin{array}{l}\mathrm{VV} \text {; absent fetal heart } \\
\text { for } 5 \text { min before deliv- } \\
\text { ery }\end{array}$ & 3160 & 34 & 31 & 75 & Withdrawal of life support & 84 & 0.42 \\
\hline 16 & 22 & 42 & M & $\begin{array}{l}\mathrm{VV} ; \text { prolonged } 2 \text { nd stage } \\
\text { midtransverse arrest }\end{array}$ & 3230 & 13 & 50 & 109 & Withdrawal of life support & 86 & 0.48 \\
\hline Mean & $\begin{array}{r}16.6 \\
\pm 5.5\end{array}$ & $\begin{array}{r}40.8 \\
\pm 1.1\end{array}$ & & & $\begin{array}{l}3131 \\
\pm 91.4\end{array}$ & $\begin{array}{r}24.8 \\
\pm 16.8\end{array}$ & $\begin{array}{r}39.0 \\
\pm 11.5\end{array}$ & $\begin{array}{r}97.0 \\
\pm 24.7\end{array}$ & & $\begin{array}{r}91.4 \\
\pm 5.5\end{array}$ & $\begin{array}{l}0.83 \\
\pm \\
0.34\end{array}$ \\
\hline
\end{tabular}

* Vaginal vertex.

† Caesarian section. 
Table 4. Clinical, laboratory, and morphometric data from cases with hypoplastic left heart syndrome

\begin{tabular}{|c|c|c|c|c|c|c|c|c|c|c|c|}
\hline Case & $\begin{array}{c}\text { Postmortem } \\
\text { interval }\end{array}$ & $\begin{array}{l}\text { Gestation } \\
\text { (wk) }\end{array}$ & Sex & Delivery & Birth (g) & Age (h) & $\mathrm{FIO}_{2}$ & $\begin{array}{c}\mathrm{PAO}_{2} \\
(\mathrm{~mm} \mathrm{Hg})\end{array}$ & $\begin{array}{c}\text { Cause of } \\
\text { death }\end{array}$ & $\begin{array}{c}\% \\
\text { Immuno- } \\
\text { positive } \\
\text { airways }\end{array}$ & $\begin{array}{l}\text { Immuno- } \\
\text { positive } \\
\text { ratio }\end{array}$ \\
\hline 17 & 30 & 42 & M & $\mathrm{VV}^{*}$ & 3300 & 62 & 21 & 50 & $\mathrm{CCF}^{+}$ & 65.4 & 0.45 \\
\hline 18 & 12 & 41 & $\mathrm{M}$ & VV & NR $\ddagger$ & 63 & 77 & 64 & $\mathrm{CCF}$ & 72.5 & 0.14 \\
\hline 19 & 18 & 41 & $\mathrm{~F}$ & VV & 3300 & 48 & 28 & 99 & CCF & 81.0 & 0.28 \\
\hline 20 & 20 & 41 & M & VV & 4470 & 43 & 30 & NR & CCF & 66.3 & 0.29 \\
\hline 21 & NR* & 40 & $M$ & VV & 3170 & 96 & 53 & 51 & CCF & 84.0 & 0.53 \\
\hline 22 & 13 & 41 & M & VV & NR & 84 & 20 & 105 & $\mathrm{CCF}$ & 71.6 & 0.58 \\
\hline 23 & 22 & 40 & M & VV & 3210 & 72 & 49 & 83 & $\mathrm{CCF}$ & 86.5 & 0.32 \\
\hline Mean & $19.2 \pm 6.6$ & $40.9 \pm 0.7$ & & & $3490 \pm 550.8$ & $66.9 \pm 18.9$ & $41.3 \pm 20.4$ & $75.3 \pm 21.8$ & & $75.3 \pm 7.9$ & $0.37 \pm 0.14$ \\
\hline
\end{tabular}

\footnotetext{
* Vaginal vertex.

$\uparrow$ Congestive cardiac failure.

$\ddagger$ Not recorded.
}

and space occupying subdural hematomata. Lung tissue from seven cases of autopsied infants who died from hypoplastic left heart syndrome in the neonatal period were used as controls. These were chosen because they had a history of minimal clinical intervention, intact brainstem function, and absence of lung disease.

Analysis of variance of birth weights, gestational ages, survival time, and postmortem interval showed no significant differences between various patient groups (Tables 1-4).

\section{METHODS}

Two to three lung samples, each representing an area of 1-2 $\mathrm{cm}^{2}$, were fixed in $10 \%$ neutral buffered formalin and embedded in paraffin. Sections stained by routine histological methods were used for general microscopic assessment, i.e. the presence or absence of meconium and the exclusion of other pathological changes. NE cells were identified by immunohistochemical staining for bombesin using the indirect immunoperoxidase method with the same antibodies and techniques as previously described (9). The degree of immunostaining for bombesin was quantified in two ways $(13,14)$. First, airways containing immunopositive cells in each case were counted and expressed as a percentage immunopositive airways. The count was performed by moving stepwise from field to field in a linear fashion from one edge to the opposite edge of the section. A minimum of 100 airways were counted per case and each count was commenced from the largest bronchus in the section, i.e. usually a mainstem bronchus. An airway was defined as a tubular structure in either longitudinal, oblique, or cross-section, lined by columnar epithelium and surrounded by a cuff of connective tissue with a variable amount of smooth muscle, i.e. a bronchiole. Where cartilage plates were associated with the surrounding cuff of connective tissue the airway was considered a bronchus. Second, the degree of bombesin staining was determined by measurement of immunoreactive area within the airway epithelium, i.e. both single cells and clustered cells, in airways ranging from $50-250 \mu$ in diameter. The measurement was performed by projecting the positive areas onto paper, using a projecting microscope with an $\times 40$ objective to give a final magnification of $\times 1200$. The outline of the immunopositive cytoplasm was drawn on paper and the area then measured with a semiautomatic image analyzer (Leitz ASM). The total immunopositive area for the individual airway cross-section was then related to the epithelial length, i.e. the circumference. The airway circumference was measured by tracing the length of the basement membrane of the bronchiolar epithelium with a map rotometer at the stated magnification. Where the epithelium had lifted off the basement membrane region, the length of epithelium was measured instead, the primary aim being to quantify the length of epithelium. The total immunoreactive area was divided by the circumference or epi- thelial length to give the immunoreactive ratio for the epithelium. The airway diameter was calibrated using the map rotometer, by measuring the distance between opposite lumenal epithelial surfaces on the short axis of the cross-section of the airway. A minimum of 30 airways were measured per case, from which the mean and SD were calculated. For statistical evaluation of data, one-way analysis of variance and Duncan's multiple range test were used (15).

\section{RESULTS}

Microscopic examination of lung sections and morphometric analysis of bombesin immunoreactive pulmonary NE cells revealed distinct differences between infants with meconium aspiration alone compared to those who had sustained brainstem damage only (Fig. $1 A$ and $B$ and 2). The number of airways containing bombesin immunoreactive cells, expressed as percentage of immunopositive airways, was significantly $(p<0.01)$ increased in patients with brainstem damage compared to those who had sustained meconium aspiration only (Table 5). Similarly the frequency of bombesin immunoreactive NE cells within the individual airways, expressed as immunopositive ratio, showed significantly $(p<0.05)$ increased mean values among patients with brainstem damage compared to those with meconium aspiration only (Table 2, Fig. 2); although there did exist a slight overlap in the actual range of values recorded. Plotted data expressing both percentage immunopositive airways and immunopositive ratio clearly demonstrate the effect of brainstem damage on bombesin-containing cells (Fig. 2). There were no significant differences either in percentage of immunoreactive airways or immunopositive ratio between cases with meconium aspiration alone versus those with hypoplastic left heart syndrome (controls).

Differences in ventilation pressures appeared not to effect the bombesin immunoreactivity of the NE cells. There was no significant difference between the cases with PFC receiving high ventilation pressures (mean, 23.5/5 $\mathrm{mm} \mathrm{H}_{2} \mathrm{O}$; range, 20/4-34/ 6) compared to cases of hypoplastic left heart syndrome, i.e. controls, of whom five were not ventilated and two of whom were ventilated at $17 / 5$ and $20 / 5 \mathrm{~mm} \mathrm{H}_{2} \mathrm{O}$. The ventilation pressures used in the cases of brainstem damage were low (mean $13 / 4 \mathrm{~mm} \mathrm{H}_{2} \mathrm{O}$; range $12 / 2-18 / 7$ ) and similar to the levels used in the ventilated controls. Those cases with combined brainstem damage and meconium aspiration were more variable (mean, $23 / 3 \mathrm{~mm} \mathrm{H}_{2} \mathrm{O}$; range $12 / 2-34 / 4$ ) presumably due to the patchy obstructive effect of meconium in the airways.

The histological examination of brain tissue from infants without clinical evidence of brainstem insult demonstrated pontosubicular necrosis associated with microglial activation in all instances but showed no evidence of necrosis in the tegmental region containing the reticular activation system and the dorsal 


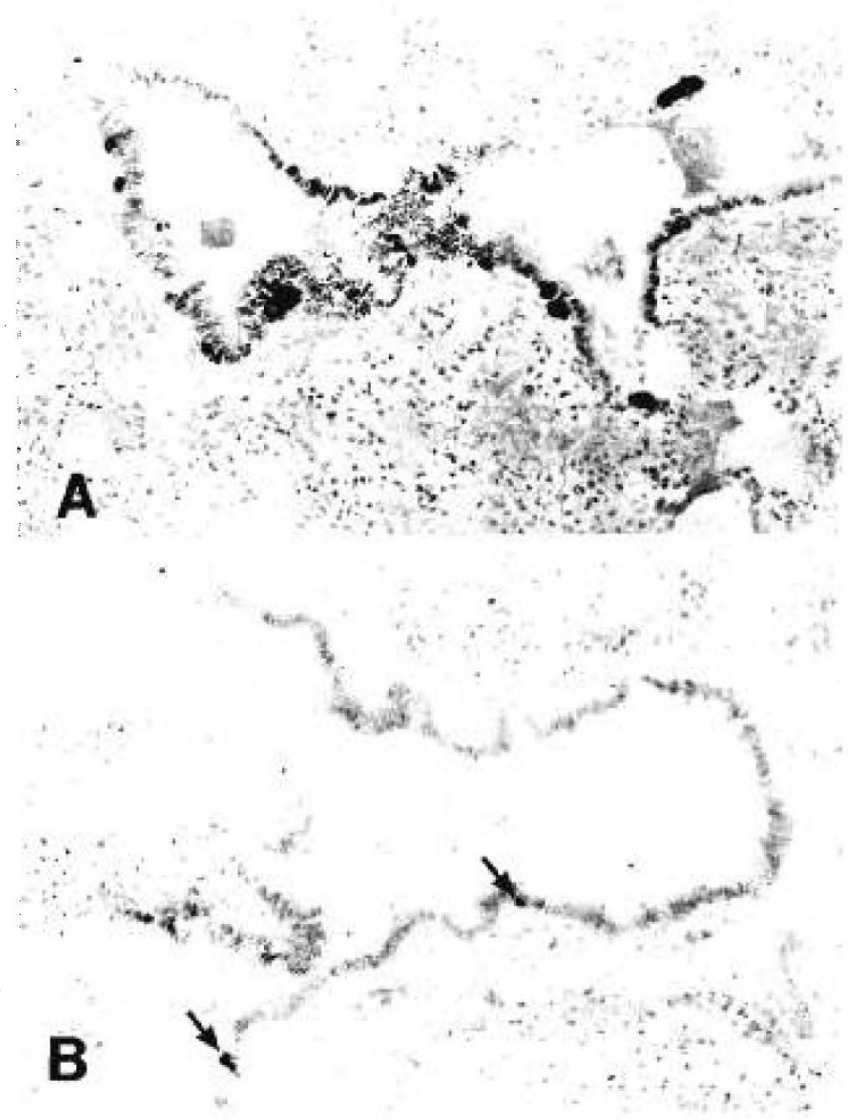

Fig. 1. Bombesin staining neuroendocrine cells in bronchioles. $A$, an infant with damage to the tegmentum of the brainstem and $B$ an infant who died from meconium aspiration syndrome, but in whom brainstem function was intact. There are distinctly greater numbers of bombesin immunopositive NE cells in associated with brainstem damage (magnification, $\times 200$ ).

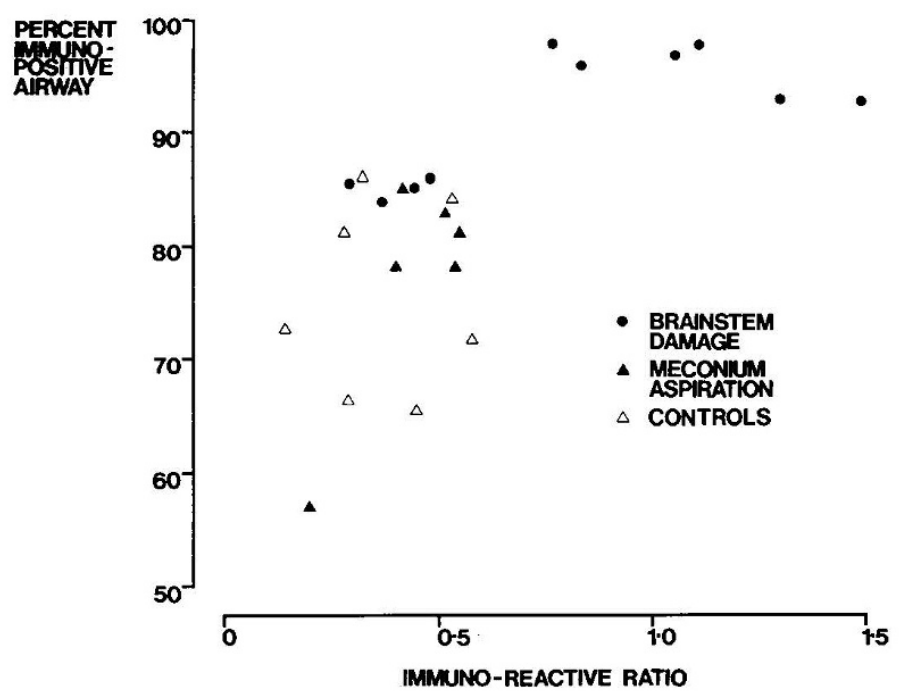

Fig. 2. The percentage immunopositive airways (vertical axis) related to immunoreactive ratio for individual cases of $(\bullet)$ brainstem damage with or without meconium aspiration; $(\boldsymbol{\Lambda})$ meconium aspiration alone, i.e. with intact brainstem function and $(\triangle)$ controls, i.e. cases of hypoplastic left heart syndrome.

nucleus of the vagus nerve. A focus of microglial activation was also present in the tegmentum in one case (case 3). Nine of the 10 infants with clinical evidence of brainstem injury had pathological changes in brain tissue. These included neuronal necrosis of the tegmentum in seven cases; gliosis of the tegmentum in two patients; pontosubicular necrosis in six; and isolated pontine necrosis in three. One patient (case 6) who lived only $5.5 \mathrm{~h}$ expectedly did not show evidence of neuronal necrosis or microglial activation.

A second unanticipated finding concerning PFC was noted when the clinical histories were correlated. PFC which invariably complicates meconium aspiration was strikingly absent in four of five patients with brainstem damage accompanied by meconium aspiration (Tables 2 and 5). Similar blood gases were also present in asphyxial brain damage which was unaccompanied by meconium aspiration as documented in Tables 3 and 5.

\section{DISCUSSION}

The pulmonary NE cells have been termed NE because of their intimate association with nerve fibers which appear simultaneously with the developing NE cells between the 8th and 10th week of gestation (16). This innervation was first described by Froelich in 1949 (17) and has since been well documented in experimental animals (18-20). On the other hand, however, there has been little published information on the innervation of the NE cells in human lungs (10-12). Recent ultrastructural studies have demonstrated adrenergic, cholinergic, and possible sensory innervation of human NE cells (21), while vagotomy studies in newborn rabbits have pointed to a significant sensory innervation derived from the Nodose ganglion (10).

In this study the effect of brainstem damage due to birth asphyxia in a group of term infants has been examined as a model of vagal denervation of the lung and its effect on bombesin-like immunoreactivity in pulmonary NE cells. Intrapartum asphyxia ranges in severity from fetal distress associated with meconium aspiration only, to widespread hypoxic damage effecting the brain, kidneys, lungs, and heart. In this series of cases there were six infants with meconium aspiration and 10 infants with brainstem damage, six of whom also had meconium aspiration. Morphometric analysis of the bombesin immunoreactive pulmonary NE cells showed a significant quantitative difference between the lungs of infants with brainstem damage versus those with intact brainstem function sustaining meconium aspiration alone. In patients with both clinical evidence of brainstem injury, and pathological changes in the tegmentum of the brainstem, the frequency and distribution of bombesin immunoreactive NE cells in lung tissue was significantly increased compared to infants with intact brain stem structure and function. The dorsal nucleus of the vagus, which is the final common pathway for efferent innervation by the brainstem to the lung, is located in the tegmentum. The correlation of these two findings indicates an inverse relationship between the brainstem activity in the area of the respiratory center and the bombesin content of the pulmonary NE cells. These findings suggest that brainstem stimuli to the lung cause release of bombesin whereas the lack of brainstem stimulus may be associated with retention of bombesin-like peptide in the cytoplasm of NE cells.

The significance of this observation is heightened because of its association with the functional state of the pulmonary vasculature, i.e. the connection between PFC and brainstem function. Normally after birth, the high fetal pulmonary vascular resistance falls with expansion and oxygenation of the lungs (11, 22 ). In persistent fetal circulation this reduction either does not occur or the resistance increases. Subsequently the pulmonary artery pressure becomes either equal to or exceeds that of the systemic artery pressure. This results in right-to-left shunting of cardiac output through the foramen ovale and ductus arteriosus causing severe hypoxia $(23,24)$. PFC may be caused by birth asphyxia, neonatal lung disease including meconium aspiration (25), and metabolic abnormalities such as acidosis (26), hypoglycemia, and hypocalcemia (24), all of which frequently complicate birth asphyxia. In this study PFC occured only in those infants with isolated meconium aspiration alone, and with one exception, it did not occur when the meconium aspiration was asso- 
Table 5. Mean $( \pm S D)$ values and statistical analysis of morphometric evaluation of bombesin-like immunoreactivity in airways, oxygen requirements $\left(\mathrm{FIO}_{2}\right)$ and blood levels $\left(\mathrm{P}_{\mathrm{AO}}\right)$ for different patient groups

\begin{tabular}{|c|c|c|c|c|c|c|c|}
\hline Diagnostic & & $n$ & Age & $\begin{array}{l}\text { ? Immunopositive } \\
\text { airways }\end{array}$ & $\begin{array}{c}\text { Immunopositive } \\
\text { ratio } \\
\end{array}$ & $\mathrm{FIO}_{2}$ & $\begin{array}{c}\mathrm{PAO}_{2} \\
(\mathrm{~mm} \mathrm{Hg}) \\
\end{array}$ \\
\hline MAS* & & 6 & $43.8 \pm 21.5$ & $77.2 \pm 9.3$ & $0.44 \pm 0.12$ & $86.3 \pm 7.4$ & $33.3 \pm 6.9$ \\
\hline $\mathrm{MAS}+\mathrm{BD}+$ & & 5 & $64.8 \pm 62.6$ & $91.7 \pm 5.5$ & $0.80 \pm 0.43$ & $51.6 \pm 0.1$ & $78.0 \pm 32.8$ \\
\hline $\mathrm{BD}$ & & 5 & $24.8 \pm 16.8$ & $91.4 \pm 5.5$ & $0.83 \pm 0.34$ & $59.0 \pm 11.5$ & $97.0 \pm 24.7$ \\
\hline $\mathrm{HLH}+$ & & 7 & $66.9 \pm 18.9$ & $75.3 \pm 7.9$ & $0.37 \pm 0.14$ & $41.3 \pm 20.4$ & $75.3 \pm 21.8$ \\
\hline \multicolumn{8}{|c|}{ Statistical Analysis - $p$ values (Duncan's multiple range test) } \\
\hline MAS & VS & $\mathrm{MAS}+\mathrm{BD}$ & NS & $<0.01$ & $<0.05$ & $<0.01$ & $<0.01$ \\
\hline MAS & VS & $\mathrm{BD}$ & NS & $<0.01$ & $<0.05$ & $<0.001$ & $<0.01$ \\
\hline MAS & VS & HLH & NS & NS & NS & $<0.001$ & $<0.01$ \\
\hline $\mathrm{MAS}+\mathrm{BD}$ & VS & $\mathrm{BD}$ & NS & NS & NS & NS & NS \\
\hline $\mathrm{MAS}+\mathrm{BD}$ & VS & HLH & NS & $<0.01$ & $<0.05$ & NS & NS \\
\hline $\mathrm{BD}$ & VS & HLH & NS & $<0.01$ & $<0.05$ & NS & NS \\
\hline
\end{tabular}

* Meconium aspiration.

$\dagger$ Brainstem damage.

$\ddagger$ Hypoplastic left heart syndrome.

ciated with brainstem damage. The explanation for the single exception was not apparent on review of the clinical or pathological data; however, the morphological assessment of the pulmonary NE cells was of "borderline" score lying between cases with and without brain damage, suggesting that despite the clinical evidence of neurological insult, the neurones responsible for pulmonary innervation survived. The data strongly suggest a functional relationship between vagal nuclei of the brainstem, control of bombesin secretion by the pulmonary NE cells, and control of pulmonary arterial blood pressure. Damage to the vagal nuclei may cause failure to discharge bombesin-like peptide from the NE cells and loss of the reflex controlling pulmonary arterial constriction. It is unlikely that bombesin itself is the direct mediator of pulmonary vasoconstriction, as there was no significant difference in bombesin content between infants with PFC associated with meconium aspiration and the control series, i.e. cases with hypoplastic left heart syndrome. This contention is further supported by recent experimental work in which administration of bombesin into pulmonary artery in lambs and rats failed to cause pulmonary vasoconstriction $(25,28)$. However, two substances, serotonin and the peptide leu-enkephalin, both known to be present in pulmonary NE cells, are strong pulmonary vasoconstrictors (27) and therefore represent more likely mediators of vasoconstriction. Bombesin on the other hand has been shown to cause bronchiole constriction in guinea pigs (29).

The findings in this study also suggest that the respiratory center of the brainstem coordinates local pulmonary vascular perfusion and ventilation in part by bombesin-mediated control of bronchiole smooth muscle tone. It is likely that such coordination originates in the dorsal nucleus of the vagus, transmitting impulses to vagally innervated NE cells, stimulating secretion of peptides which in turn exert a local control on both pulmonary vasculature and bronchiole smooth muscle. Apart from autonomic motor innervation suggested by this study and others (13); there is now convincing evidence from studies in neonatal rabbits that NEB cells have vagal sensory innervation (10). These combined afferent and efferent innervations suggest the presence of a reflex arch system connecting the brainstem via the vagus to at least part of the pulmonary NE cell system. The afferent arm of the reflex being sensitive to the level of oxygen (30) and possibly other qualitative aspects of inspired air; the efferent response stimulating the secretion of serotonin $(16,30-32)$ and peptides which mediate the local tissue response. This hypothetical reflex clearly confines itself to the role of vagal innervation of the NE cells and as with any reflex, would be subject to augmentary and inhibitory influences. It makes no attempt to explain the role of recently described adrenergic nerve junctions within NE cell bodies (11) and is open to the criticism that the recently described sensory innervations (10) arise in the Nodose ganglion in the neck rather than the brainstem. However, the latter work was performed in neonatal rabbits which appear to have NE cell bodies which are morphologically different from those of humans (34).

The proposed homeostatic role of bombesin and the NE cells does not preclude the recent suggestion that bombesin acts as a lung growth factor (35). Low oxygen tension in the airways is known to increase the rate of alveolar growth (36) and cause degranulation of the NE cells (31). It is therefore possible that bombesin may in fact be the mediator of increased lung growth in response to hypoxia. These suggestions are clearly speculative and require further investigations.

\section{REFERENCES}

1. Feyrter F 1938 Uber diffuse endokrine epitheliale Organe. JA Barth, Leipzig, pp 6-17

2. Bensch KG, Gordon GB, Miller LR 1965 Studies on the Bronchial Counterpart of the Kultschitzky (argentaffin) cell and innervation of Bronchial Glands. J Ultrastuct Res 12:668-686

3. Cutz E, Conen PE 1972 Endocrine-like cells in human fetal lung: an electron microscopy study. Anat Rec 173:115-122

4. Cutz E, Chan W, Wong V, Conen PE 1975 Ultrastructure and fluorescence histochemistry of endocrine (APUD type) cells in tracheal mucosa of human and various animal species. Cell Tissue Res 158:425-437

5. Lauweryns JM, Cokelaera M, Thewnynck P 1972 Neuro-epithelial bodies in the respiratory mucosa of various mammals: a light optical, histochemical and ultrastructural investivation. Zellforsch Mikrosk Anat 135:569-592

6. Pearse AGE 1969 The cytochemistry and ultrastructure of polypeptide hormone-producing cells of the APUD series and the embryologic, physiologic and pathologic implications of the concept. J Histochem Cytochem 17:303313

7. Said SI, Mutt V 1969 Long acting vasodilator peptide from lung tissue. Nature (Lond) 224:699-700

8. Wharton JJ, Polak LM, Bloom SR 1978 Bombesin-like immunoreactivity in the lung. Nature (Lond) 273:769-770

9. Cutz E, Chan W, Track NS 1981 Bombesin calcitonin and leu-enkephalin immunoreactivity in endocrine cells of human lung. Experientia 37:765767

10. Lauweryns JM, Van Lommel A 1983 The intrapulmonary neuroepithelial bodies after vagotomy: demonstration of their sensory neuro receptor-like innervation. Experientia 39:1123-1124

11. Stahlman MT, Gray ME 1984 Ontogeny of neuroendocrine cells in human fetal lung I. An electron microscopic study. Lab Invest 51:449-463

12. Lauweryns JM, Peuskens JC 1972 Neuro-epithelial bodies (neuroreceptor or secretory organs?) in human infant bronchial and bronchiolar epithelium. Anat Rec 172:471-482

13. Cutz E, Gillan JE, Track NS 1984 Pulmonary endocrine cells in developing human lung and during neonatal adaption. In: Becker LK, Gazdar A, eds Endocrine Lung in Health and Disease. WB Saunders Co, Philadelphia, pp 210-231

14. Cutz E, Gillan JE, Bryan AC 1985, Neuroendocrine cells in the developing human lung-morphologic and functional associations. Pediatr Pulmonol 
$1:($ suppl):S21-S29

15. Kramer CY 1956 Extension of multiple range tests to group means with unequal numbers of replications. Biometrics 12:307-310

16. Hernandez-Vasquez A, Will JA, Quay WB 1978 Quantitative characteristics of the Feyrter cells and neuroepithelial bodies of the fetal rabbit lung in normoxia and short term chronic hypoxia. Cell Tissue Res 189:179-186

17. Frolich F 1949 Die "helle Zelle" der Bronchialschleimhaut and ihre Beziehungen zum Problem der Chemoreceptoren. Frankfurt Pathol 60:517-559

18. Cutz E, Chan W, Wong V, Conen PE 1974 Endocrine cells in rat fetal lungs. Lab Invest 30:458-464

19. Hung KS, Hertiweck MS, Hardy JD, Loosli CG 1973 Ultrastructure of nerves and associated cells in bronchiolar epithelium of the mouse lung. $J$ Ultrastruct Res 43:426-437

20. Wasano K, Yamamoto T 1981 A scanning and transmission electron microscopic study on neuroepithelial bodies in the neonatal mouse lung. Cell Tissue Res 216:481-490

21. Stahlman MT, Gray ME 1982 Innervation of human intrapulmonary neuroepithelial cells. Pediatr Res 16:362A (abstr)

22. Dawes GS 1968 Foetal and Neonatal Physiology. Chicago Year book Medical Publishers Inc, Chicago

23. Gersony WM, Duc GV, Sinclair JC 1969 "PFC" syndrome (persistence of the fetal circulation). Circulation 40:III-87 (abstr)

24. Gersony WM 1984 Neonatal pulmonary hypertension: pathophysiology, classification and etiology. Clin Perinatol 11:517-523

25. Fox WW, Gewitz MH, Dinwiddle R 1977 Pulmonary hypertension in perinatal aspiration syndromes. Pediatrics 59:205-211
26. Rudolph AM, Yuan S 1966 Response of the pulmonary vasculature to hypoxia and $\mathrm{H}+$ ion concentration changes. J Clin Invest 45:399-404

27. Gillespie MN, Reinsel CN, Bowdy BD 1984 Pulmonary vasoactivity of lung endocrine cell-related peptides. Peptides 5:21-24

28. Kulik TJ, Johnson DE, Elde RP, Lock JE 1983 Pulmonary vascular effects of bombesin and gastrin-releasing peptides in conscious newborn lambs. $\mathrm{J}$ Appl Physiol 55:1093-1097

29. Impicciatore M, Bertaccini G 1973 The bronchoconstrictor action of tetradecapeptide bombesin in the guinea pig. J Pharm Pharmacol 25:872-875

30. Lauweryns JM, Cokalaere M, Lerut T, Thewnynck P 1978 Cross-circulation studies on the influence of hypoxia and hypoxaemia on neuroepithelial bodies in young rabbits. Cell Tissue Res 193:373-386

31. Lauweryns JM, DeBock V, Guelinckx P, Decramer M 1983 Effects of unilateral hypoxia on neuroepithelial bodies in rabbit lungs. J Appl Physiol Respir 55:1665-1668

32. Moosavi H, Smith P, Heath D 1973 The Feyrter cells in hypoxia. Thorax 28:729-741

33. Hernandez-Vasquez A, Will JA, Quay WB 1977 Quantitative characteristics of the Feyrter (APUD) cells of the neonatal rabbit lung in normoxia and hypoxia. Thorax 32:449-456

34. Cutz E 1974 Neuro-endocrine (APUD-type) cells of the lung. In: Motta PM (ed) Ultrastructure of Endocrine Cells and Tissue. Martinus Nijhoff Publishers, Boston, pp 148-158

35. Kolata G 1982 Cell biology yields clue to lung cancer. Science 218:38.

36. Bartlett D, Remmers JE 1971 Effects of high altitude exposure on the lungs of young rats. Respir Physiol 13:116-125

\section{Announcement}

From Man to Gene, from Gene to Man

International Symposium, Florence, November 1-4, 1986

Invited faculty: J.A. Abrisqueta, E. Barolo, K. Berg, A. Cao, L. Cavalli Sorza, R. Ceppellini, E. Cittadini, M. Conforti, G. Dal

Porto, A. de la Chapelle, P. Devroey, A. Falaschi, M. Fraccaro, J. Frezal, H. Galjaard, D.J. Galton, F. Giannelli, R.M. Goodman, B. Hadorn, C. Inglese, M. Jahoda, M. Jeanpierre, M.F. Lechat, L. Luzzatto, I. Magli, J.F. Mattei, M.G. Mattei, A. Milunsky, R.H. Mnookin, J. Nielsen, M. Pembrey, P. Polani, J. Rubellin Devichi, J. Steptoe, A. Van Seirteghem, J. Warson, B. Wainuright.

Main topics: Technology of the "New Genetics." Direct analysis of DNA. Genetics Engineering. Science and Technology to allow the developing of life. "New Genetics," Bioethics and Morality. Genetics and Law. Diagnosis, Control and Prevention of Birth Defects.

Organizing committee: G. Bartolozzi, M.L. Giovannucci Uzielli, Department of Paediatrics, Via L. Giordano 13, 50132 Florence Italy. Tel (055) 58.46.63. 